\title{
FILLING THE LIMPET GAP: MOLECULAR CHARACTERIZATION OF THE GENUS PATELLA (PATELLIDAE, GASTROPODA) IN THE ALGERIAN COASTS OF ORAN
}

\author{
Mohammed Mustapha Kallouche ${ }^{1}$, Iván Acevedo ${ }^{2}$, Mohcen Ghalek ${ }^{1}$ \\ Djilali Bouras ${ }^{1}$ and Annie Machordom ${ }^{2}$ \\ ${ }^{1}$ Faculty of Life Sciences, University of Oran1 Ahmed Ben Bella \\ El Mnaouar Box 1524, Oran, Algeria \\ E-mails:mus.kallouche@gmail.com; mohceng@yahoo.fr; dilalbouras@gmail.com \\ ${ }^{2}$ Museo Nacional de Ciencias Naturales (MNCN-CSIC) \\ José Gutiérrez Abascal 2, 28006, Madrid, Spain \\ E-mails: iacevedo@mncn.csic.es; annie@mncn.csic.es
}

Several molecular studies have been conducted on northeastern Atlantic and Mediterranean patellid limpets, but Algerian specimens have never been included in these studies. This work intends to fill this gap and characterize populations of different Patella species inhabiting the Algerian coasts of Oran, clarifying the presence of Patella ferruginea that is considered as endangered. Moreover, comparison of their intraspecific variation with that of other areas might enlighten about populations connectivity and the conservation status of the analysed species.

The molecular analyses performed on the samples from Oran's coasts, confirmed the presence of Patella ferruginea, P. rustica and P. caerulea, all of which shared haplotypes with other Mediterranean localities previously analysed. The intraspecific differentiation was limited, with the exception of $P$. rustica, which showed the greatest diversity, while $P$. ferruginea, the most endangered species, showed the lowest.

Key words: population diversity, invertebrates, biodiversity, genetics, endangered species.

\section{INTRODUCTION}

Proper conservation strategies require knowing species' distribution and population differentiation to better preserve its genetic pool, i.e. the entire genetic richness of the species (WEEKs et al. 2016). Local adaptations can lead to a certain level of genetic differentiation, while still maintaining a cohesive general structure in a metapopulation framework. Gene flow among populations determines the level of differentiation or homogeneity. Distance between populations, habitat discontinuity, and species dispersal capabilities are some factors that can affect gene flow. Thus, knowledge of the entire distribution of a given species is necessary for better understanding their status and, consequently, ensuring their adequate protection and management.

In the case of western Mediterranean patellids, until more recently, little was known of their taxonomic status and distribution along the Algerian coast with the exception of PALLARY (1900), who first cited the presence of 
patellids in the area. Since then, Frenkiel (1975), Frenkiel and Moü̈za (1982), Semroud and Boumaza (1998), Boumaza and Semroud (2001), Kallouche et al. (2011, 2012, 2014a), and BELDI et al. (2012) studied different aspect about their ecology and biology, while Maatallah and Djebar (2014) performed ecotoxicological analyses. However, molecular phylogenetic studies of patellids in this area have not been conducted.

Limpets are abundant and familiar inhabitants of intertidal rocky shores worldwide from tropical to polar regions, playing important roles in littoral marine ecosystems (BRANCH 1985). Limpets of the genus Patella Linnaeus, 1758 are widespread along the north-eastern Atlantic intertidal rocky shores and have been extensively studied in terms of population dynamics, ecology, and phylogeography (e.g., Lewis \& Bowman 1975, Sà-Pinto et al. 2005, Casu et al. 2006, Cabral 2007, Rivera-Ingraham et al. 2011a, Cossu et al. 2015, 2017). Patellid species have similar life cycles with a short planktonic larval stage during which current-driven dispersal occurs. Because their supposedly limited dispersal ability, and therefore theoretical small-scale differentiation, population level genetic analyses are required to understand phylogeographic and microevolutionary processes. Assessing genetic structure among populations along the species range and across boundaries is key for understanding the mechanisms that shape a species' current distribution. Moreover, they may serve as a model for addressing specific conservation-related questions as some limpet species are included in red lists and others have been massively overexploited. Currently 12 valid species are recognized along the Mediterranean and north-eastern Atlantic coasts: Patella aspera Röding, 1798, P. caerulea Linnaeus, 1758, P. candei d'Orbigny, 1840, P. depressa Pennant, 1777, P. ferruginea Gmelin, 1791, P. lugubris Gmelin, 1791, P. natalensis Krauss, 1848, P. pellucida Linnaeus, 1758, P. piperata Gould, 1846, P. rustica Linnaeus, 1758, P. ulyssiponensis Gmelin, 1791, and P. vulgata Linnaeus, 1758) (Gofas 2015). However, a recent study (Mmonwa et al. 2017) undoubtedly identified P. natalensis as belonging to the genus Scutellastra H. Adams et A. Adams, 1854 . Moreover, SÀ-PINTo et al. $(2005,2008,2010,2012)$ proposed to reconsider the species $P$. orientalis (Pallary, 1938), before synonymised as P. rustica, following the genetic differentiation found between these two species.

In the Mediterranean Sea, the genus Patella is represented by four species: P. caerulea, P. ulyssiponensis, P. rustica, and P. ferruginea (Sella et al. 1993, MauRo et al. 2003, Templado 2011). Additionally, SÁ-Pinto et al. (2010) suggested that one of the three differentiated $P$. rustica lineages they found around the Adriatic and Aegean seas could represent a cryptic species: P. orientalis. While $P$. ferruginea is restricted to the southwestern part of the Mediterranean, the other species are distributed and commonly found throughout the entire basin. These species occur sympatrically along the Mediterranean rocky shores, but inhabit different vertical zones. Patella rustica inhabits the upper intertidal 
zone, while $P$. caerulea and $P$. ulyssiponensis inhabit the lower zone on sheltered rocks or rocks exposed to wave action, respectively (SElla et al. 1993).

Along the Algerian coasts, the presence of three species, $P$. ferruginea, $P$. caerulea and P. rustica, was previously cited (Kallouche 2014a). Other patellids such as $P$. vulgata (Kallouche 2014a), $P$. intermedia ( $=P$. depressa) and $P$. ulyssiponensis (BELDi et al. 2012), were also reported. However, some of these specimens were probably misidentified and likely represent $P$. ulyssiponensis, since $P$. vulgata and $P$. depressa are exclusively distributed in the Atlantic Ocean.

Significant variability in limpets was previously reported (MAUro et al. 2003). Indeed, highly variable Patella haplotypes were found over short distances, while others were present over long distances (SÁ-PINTo et al. 2005). Therefore, the purpose of this study is to compare Algerian coastal limpets with other Mediterranean populations, assessing genetic variation and verifying whether there are local adaptations or, on the contrary, certain genetic homogeneity.

Patella ferruginea is considered endangered (Boudouresque et al. 1996) and is included in the annexes of endangered or threatened species of the Barcelona and Bern Conventions and in the European Habitat Directive (TemplaDo et al. 2004). Thus, its disappearance from several areas (such as most mainland European coasts) has led to a variety of protection protocols that have been implemented in an effort to preserve remaining populations (TEMPLADO et al. 2004, Guallart \& Templado 2012, Guallart et al. 2013a). Therefore, the study of this species is particularly important. Although currently distributed mainly along the coast of North Africa, from north-eastern Morocco to Algeria and Tunisia, some populations remain in Corsica (LABOREL-Deguen \& Laborel 1991), Sardinia (Doneddu \& Manunza 1992, Porcheddu \& Milella 1991), and the southern coast of Spain (Espinosa 2006, Guallart \& TEMPlado 2012). As a broadcast spawner, the patchy distribution and small effective population size of $P$. ferruginea will likely lead to poor local reproductive success (Rivera-Ingraham et al. 2011b, Guallart et al. 2013b). A patchy distribution combined with a lack of contact among populations and continued pressure from human activities are certain to impact local survival and genetic diversity (МасновDOM et al. 2010). Thus, knowledge of a given species' exact distribution and population status is essential to properly undertake conservation and management measures.

Thus, our overall aim is to molecularly characterize Algerian Patella populations and examine potential population differentiation, thus providing more molecular data of the species inhabiting the Maghrebian coasts and contributing to the successful management of such species, particularly of the critically endangered P. ferruginea. Hence, we combined phylogenetic and phylogeographic tools to better characterise the genetic structure of Patella populations and the potential factors determining the patterns (or lack of) gene flow among populations. 


\section{MATERIAL AND METHODS}

\section{Sampling and data collection}

Samples were collected in three sites (Madagh II, Oran Port and Kristel), with the corresponding permission from western Algeria (Fig. 1) along the Oran and Ain Temouchent coasts. To avoid populations disturbance, and taking into account the endangered condition of some of them, a minimum number of individuals were sacrificed and included in the collections of our institutions, as references. Samples were morphologically identified, some measures taken and external features recorded, mostly for the differentiation of the two previously described forms of Patella ferruginea: "lamarcki" and "rouxi" (PAyraudeau 1826). Unfortunately, none of the sampled specimens were identified as $P$. ulyssiponensis. Thus, a total of 28 specimens were collected and classified as 6 P. caerulea, 8 P. rustica, and 14 of both forms of $P$. ferruginea (Table 1 ).

Additionally, 82 mitochondrial cytochrome oxidase subunit I (COI) sequences available from GenBank were included in our dataset. For each Patella species haplotype pre-

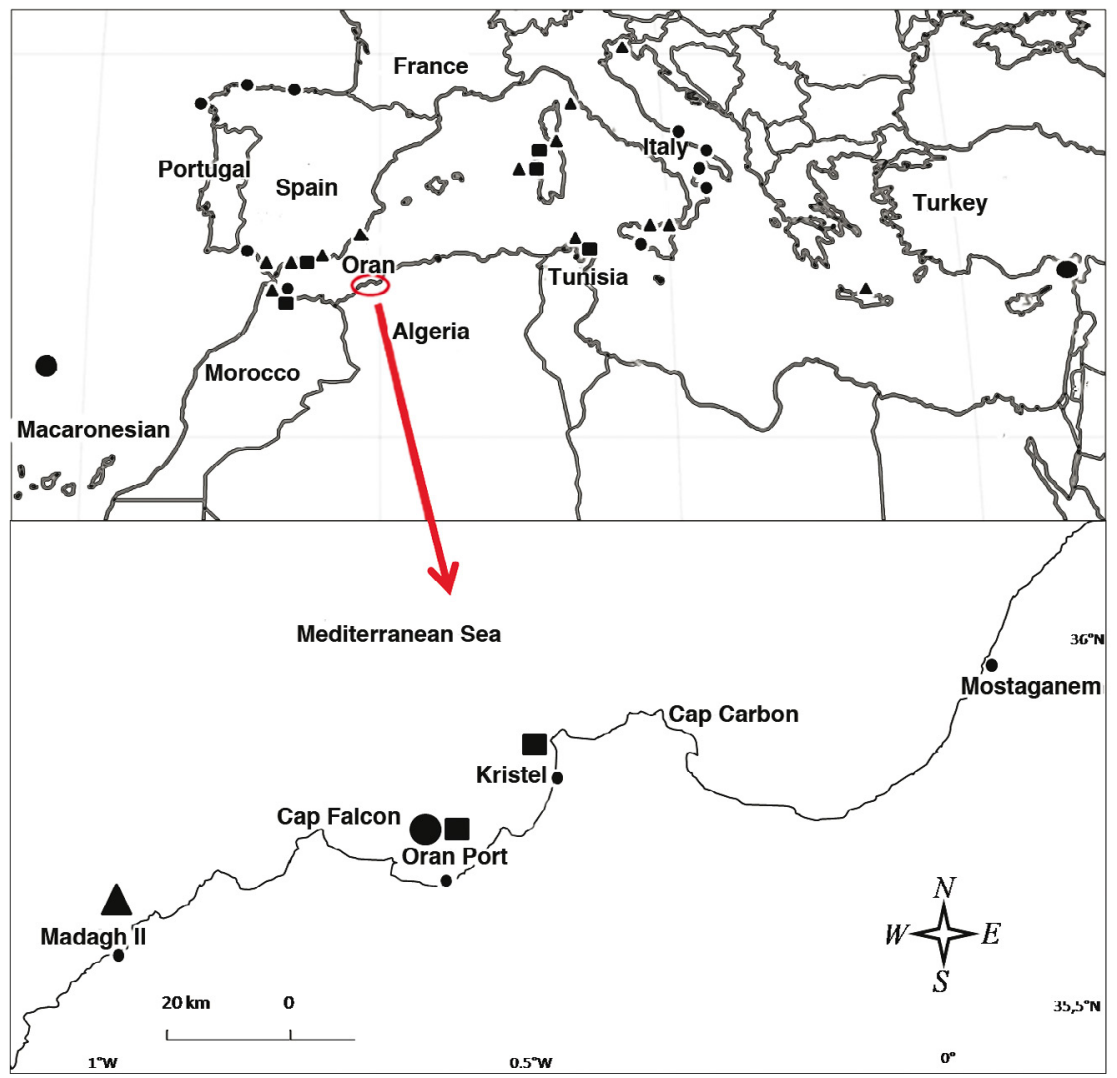

Fig. 1. Map of the geographic locations of the Patella sequences downloaded from the GenBank and the studied zone (western coast of Algeria). Legend: $\boldsymbol{\Delta}=$ P. caerulea, $\mathbf{\square}$ P. ferruginea, $\bullet$ P. rustica 
Table 1. Localization and GenBank accession numbers of Patella species collected from Algeria.

\begin{tabular}{|c|c|c|c|c|}
\hline Region & Localization & Species & Reference & GenBank acc. number \\
\hline \multirow[t]{6}{*}{ Madagh II } & $35.632936 \mathrm{~N}, 1.071474 \mathrm{~W}$ & P. caerulea & Pc1 & KX792528 \\
\hline & & & Pc2 & KX792529 \\
\hline & & & Pc3 & KX792530 \\
\hline & & & Pc4 & KX792531 \\
\hline & & & Pc5 & KX792532 \\
\hline & & & Pc6 & KX792533 \\
\hline \multirow[t]{15}{*}{ Oran Port } & 35. $42811 \mathrm{~N}, 0.393591 \mathrm{~W}$ & P. rustica & Prus1 & KX792534 \\
\hline & & & Prus2 & KX792535 \\
\hline & & & Prus3 & KX792536 \\
\hline & & & Prus4 & KX792537 \\
\hline & & & Prus5 & KX792538 \\
\hline & & & Prus6 & KX792539 \\
\hline & & & Prus7 & KX792540 \\
\hline & & & Prus8 & KX792541 \\
\hline & & P. ferruginea & Pf537 & KX792542 \\
\hline & & & Pf539 & KX792543 \\
\hline & & & Pf541 & KX792544 \\
\hline & & & Pf545 & KX792545 \\
\hline & & & Pf550 & KX792546 \\
\hline & & & Pf562 & KX792547 \\
\hline & & & Pf569 & KX792548 \\
\hline \multirow[t]{7}{*}{ Kristel } & $35.877224 \mathrm{~N}, 0.296423 \mathrm{~W}$ & P. ferruginea & Pf504 & KX792549 \\
\hline & & & Pf505 & KX792550 \\
\hline & & & Pf506 & KX792551 \\
\hline & & & Pf507 & KX792552 \\
\hline & & & Pf508 & KX792553 \\
\hline & & & Pf509 & KX792554 \\
\hline & & & Pf510 & KX792555 \\
\hline
\end{tabular}

sent in the Mediterranean and close Atlantic, only one specimen was selected. Table 1 lists the Algerian specimens; Table 2 lists the additional limpet specimens analysed.

For the phylogenetic reconstruction, Cymbula safiana (Lamark, 1819) was selected as an outgroup. This limpet was previously considered as belonging to Patella but, based on molecular analysis, is now included in a different genus of the family Patellidae (SÁ-PINTO et al. 2005, NaKano \& Ozawa 2007). 


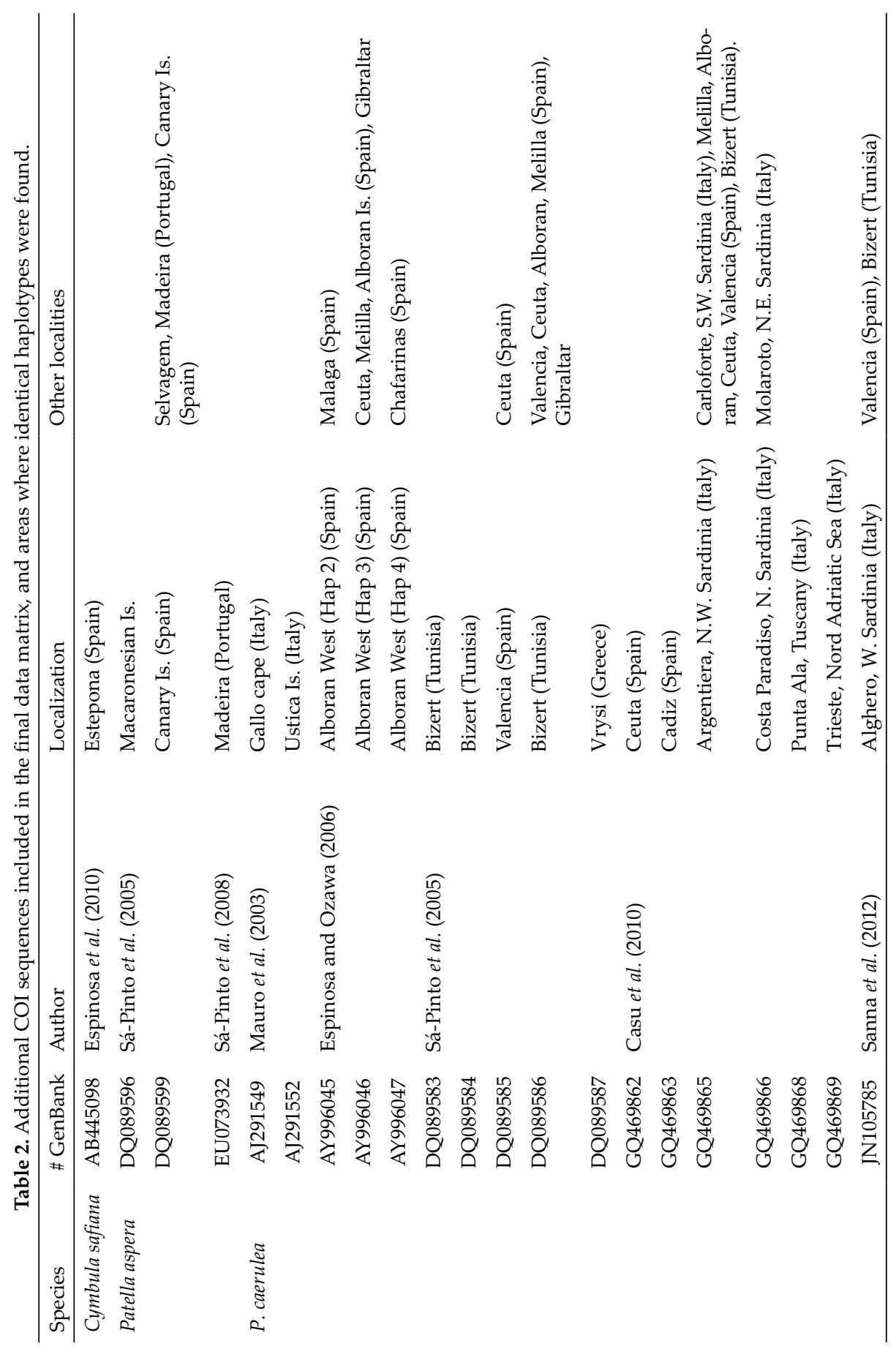




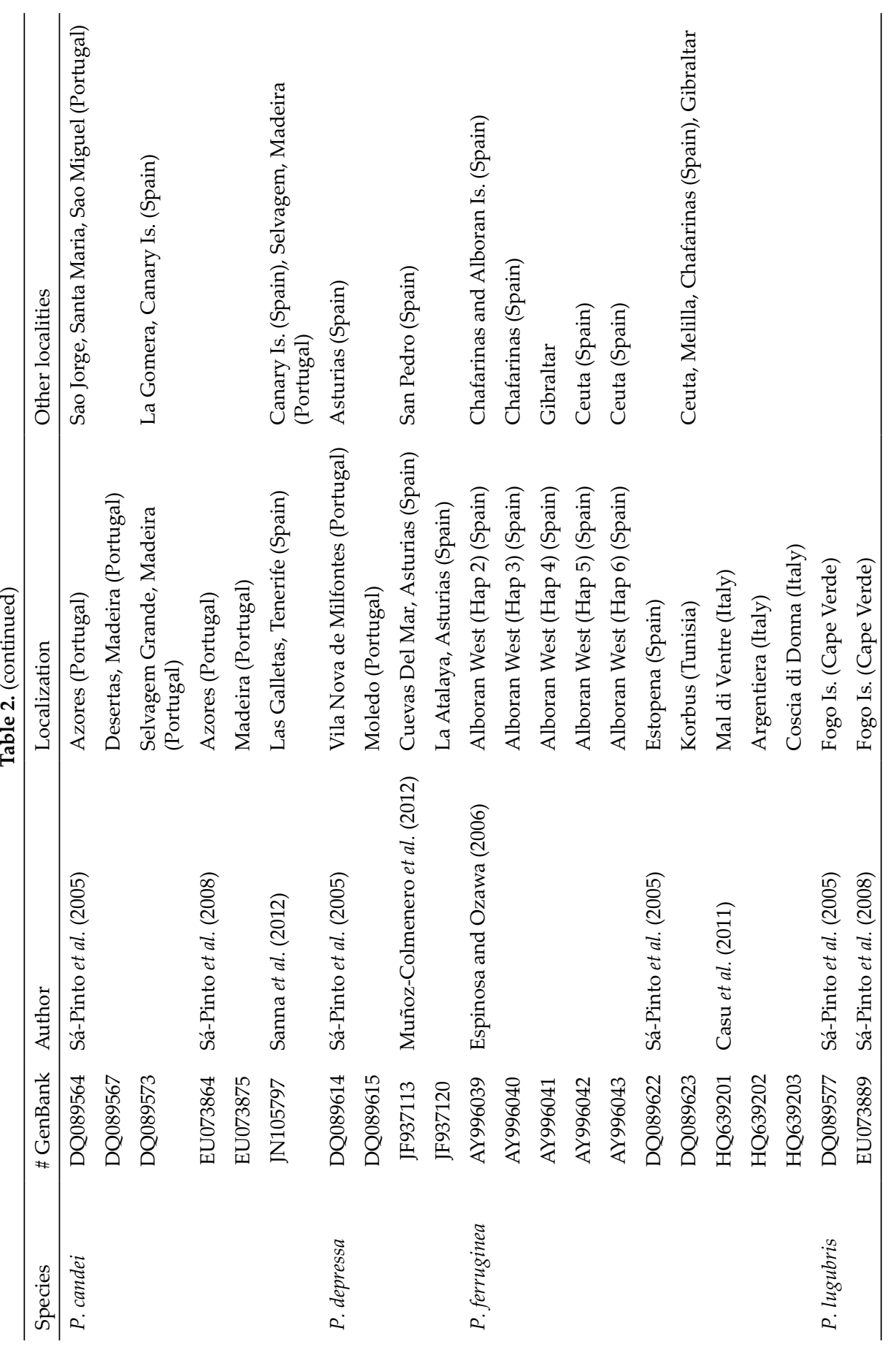




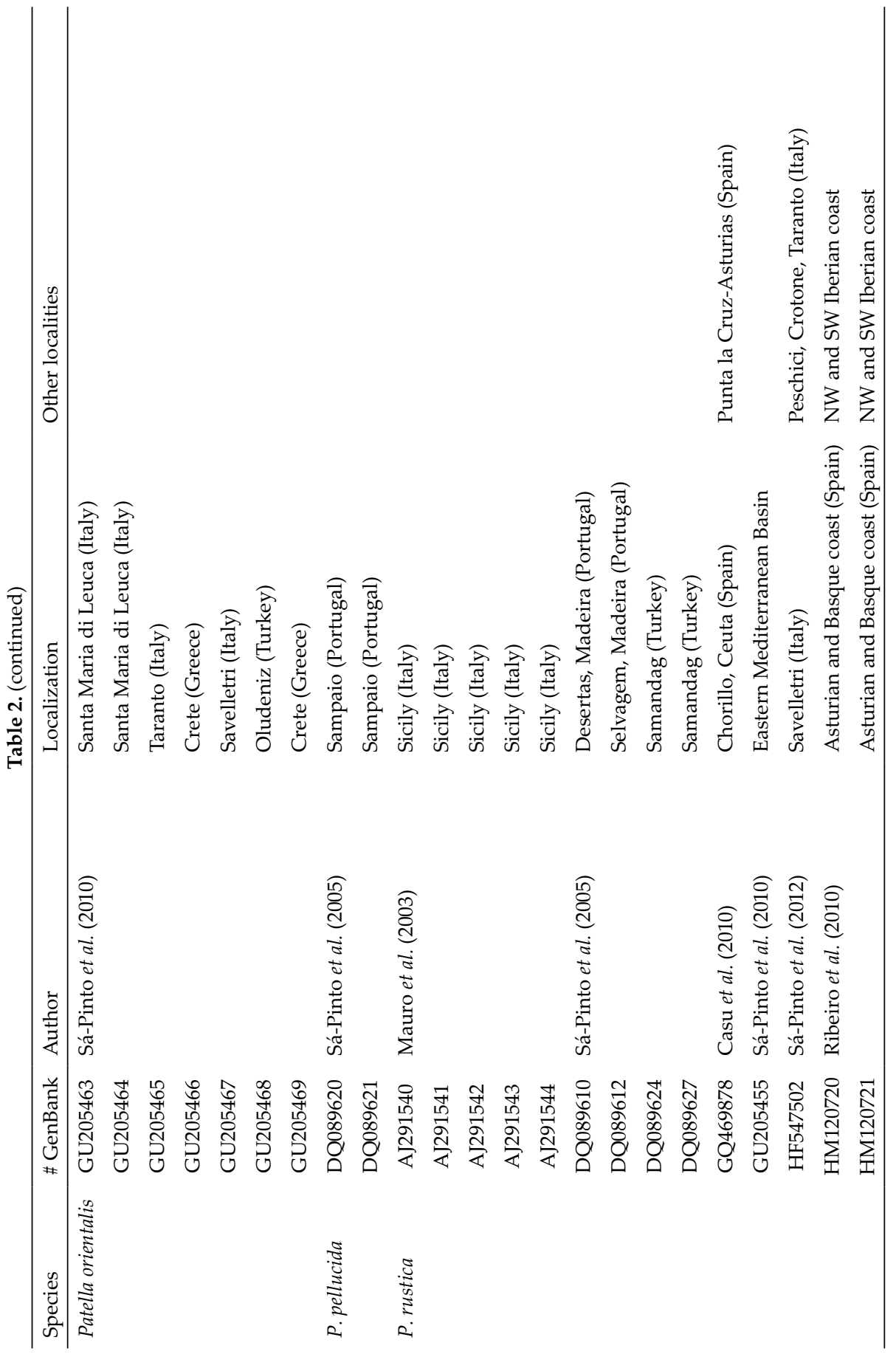




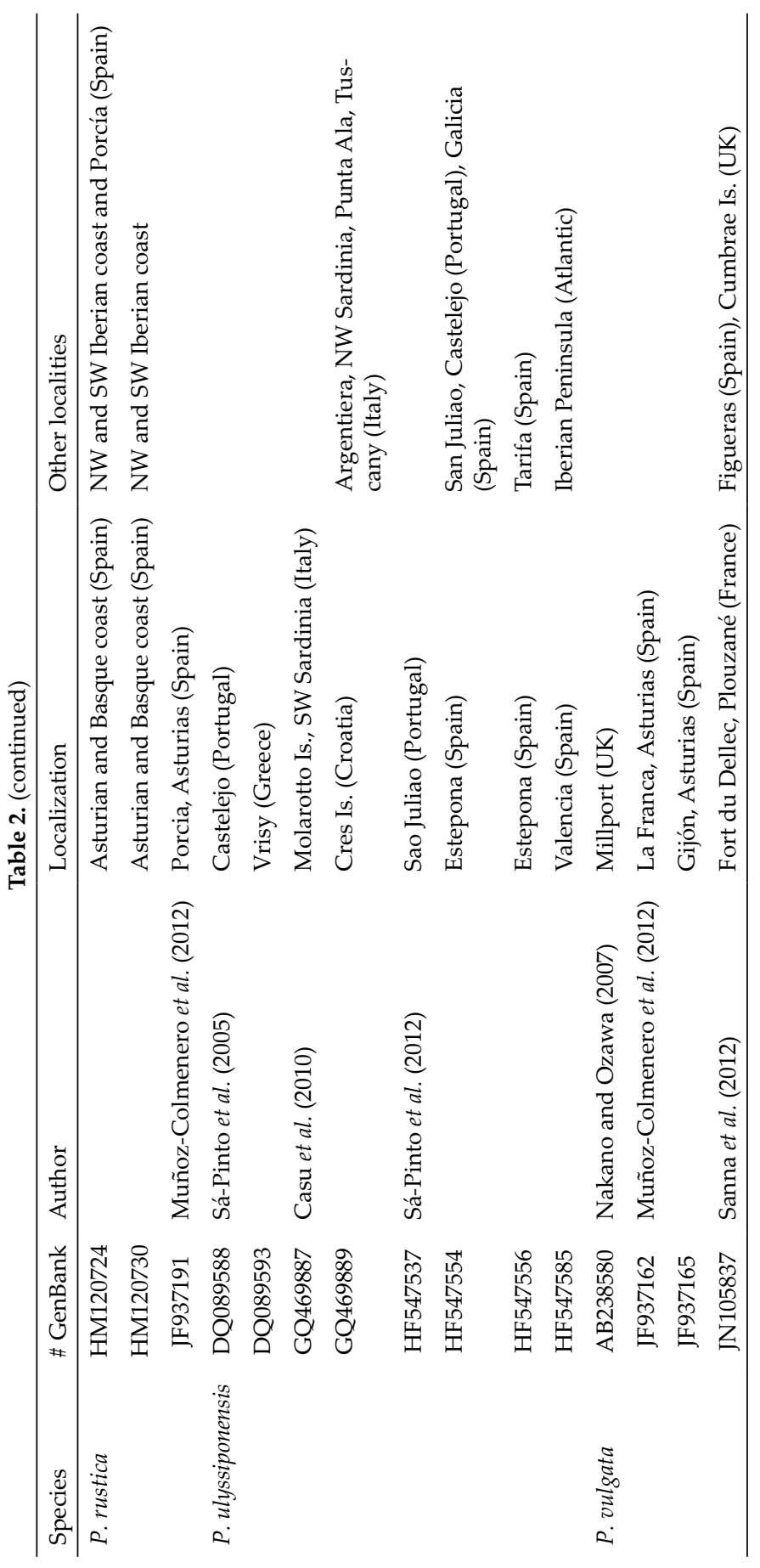




\section{DNA extraction and PCR amplification}

Total DNA was extracted from pieces of foot muscle preserved in absolute ethanol. After digesting the tissue with proteinase $\mathrm{K}$ overnight, genomic extraction was performed using the DNeasy kit (Qiagen), following the manufacturer's protocol.

The polymerase chain reaction (PCR), carried out in a total volume of $50 \mu \mathrm{l}$, contained $2 \mu \mathrm{l}$ of a 1:20 dilution of total genomic DNA, 1.25 U of Taq DNA Polymerase (Biotools), 1× reaction buffer, $2 \mathrm{mM}$ of $\mathrm{MgCl}_{2}, 0.16 \mu \mathrm{M}$ of both LCO1490 and COI-H primers (Folmer et al. 1994, МасновDом et al. 2003), and $0.2 \mathrm{mM}$ of a dNTPs mix.

PCR amplifications were conducted in thermal cyclers under the following conditions: initial denaturation at $94{ }^{\circ} \mathrm{C}$ for 4 minutes, followed by 40 cycles at $94{ }^{\circ} \mathrm{C}$ for $45 \mathrm{sec}-$ onds, $48^{\circ} \mathrm{C}$ for 1 minute, and $72{ }^{\circ} \mathrm{C}$ for 1 minute. A final extension at $72{ }^{\circ} \mathrm{C}$ for 10 minutes was performed prior to cooling to $10^{\circ} \mathrm{C}$.

Both positive and negative controls were included in all amplifications. To verify the positive amplification and amplicon size, PCR products were run on $0.8 \%$ agarose gels (TBE buffer) at $90 \mathrm{mV}$ for 50 minutes. PCR products were purified by ethanol precipitation. The final BigDye Terminator reaction and sequencing of both strands were performed by the SECUGEN service (Spain).

\section{Data analysis}

Cytochrome c oxidase subunit I (COI) sequences were trimmed to 658 base pairs fragments (removing primer ends); no gap was necessary for the alignment. All new haplotypes were submitted to GenBank (accession numbers KX792528 to KX792555). The matrix obtained was combined with the data downloaded from GenBank (Table 2).

To verify the species and lineage adscription of the samples collected, phylogenetic reconstructions were developed with the specimens here sequenced together with the GenBank haplotype references. Maximum parsimony (MP; PAUP v. 4.0a, Swofford 2002), maximum likelihood (ML; PHYML v. 3.0, GuIndon et al. 2010) and Bayesian inference (BI; MrBayes v.3.2, Huelsenbeck \& Ronquist 2001, Ronquist \& Huelsenbeck 2003) methods were used to test the phylogenetic relationships of sequenced samples. To test the support of MP and ML results, 1000 bootstrap pseudoreplicates were performed. For the BI analysis, two parallel runs of $2 \times 10^{6}$ repetitions were done, sampling one in every 1000 trees and discarding the first $25 \%$ as burn-in; node support was evaluated by posterior probabilities.

Haplotype networks for $P$. caerulea, $P$. rustica, and $P$. ferruginea were analysed independently with Haplotype Viewer (http://www.cibiv.at/ greg/haploviewer), to situate the Algerian haplotypes among the biogeographical variation of each species.

\section{RESULTS}

\section{Phylogenetic lineages recognition}

The phylogenetic tree obtained (Fig. 2) shows four main clusters. The first one included specimens belonging to $P$. caerulea, $P$. candei, $P$. lugubris, and $P$. depressa. However, some samples considered as $P$. candei were differentiated 
from the main group and clustered as the sister group of $P$. lugubris, instead of with the other conspecific samples. Algerian and Mediterranean samples of $P$. caerulea clustered together, showing no preferential phylogenetic association among samples from the southwestern Mediterranean Sea (Bizert, Oran, Gibraltar), Greece, Sardinia or Spanish and Italian coasts.

Another cluster consisted of haplotypes corresponding to P. aspera, $P$. vulgata, and $P$. ulyssiponensis. However, similar to the case of $P$. candei, $P$. aspera haplotypes did not group all together: one haplotype grouped with $P$. vulgata, while the others grouped with some P. ulyssiponensis specimens.

A third cluster contained haplotypes of $P$. ferruginea, $P$. rustica and $P$. orientalis. Within the clade of $P$. rustica, no apparent phylogeographic structure has been recovered, even between Atlantic and Mediterranean (eastern or western) haplotypes. Patella ferruginea specimens clustered in a well-supported monophyletic assemblage in which the haplotypes showed few differences. The Algerian specimens were included within this group. The specimens here named as P. orientalis, according to SÀ-PINTo et al. $(2005,2008,2010$, 2012), previously considered as $P$. rustica, formed a well differentiated sub-

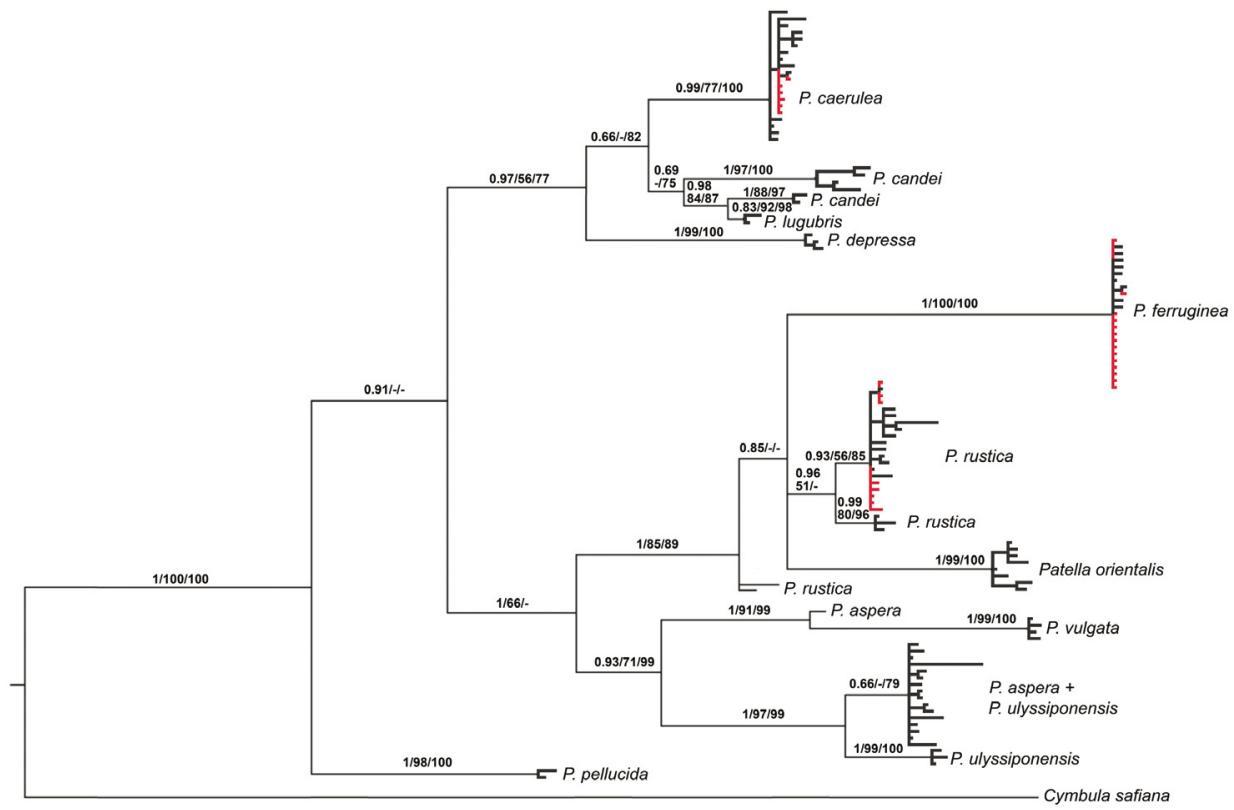

Fig. 2. Phylogenetic tree based on Bayesian inference of Patella species. Numbers on branches represent posterior probabilities based on Bayesian inference analysis and bootstrap values based on maximum parsimony and maximum likelihood analyses, respectively. Red branches represent Algerian samples 


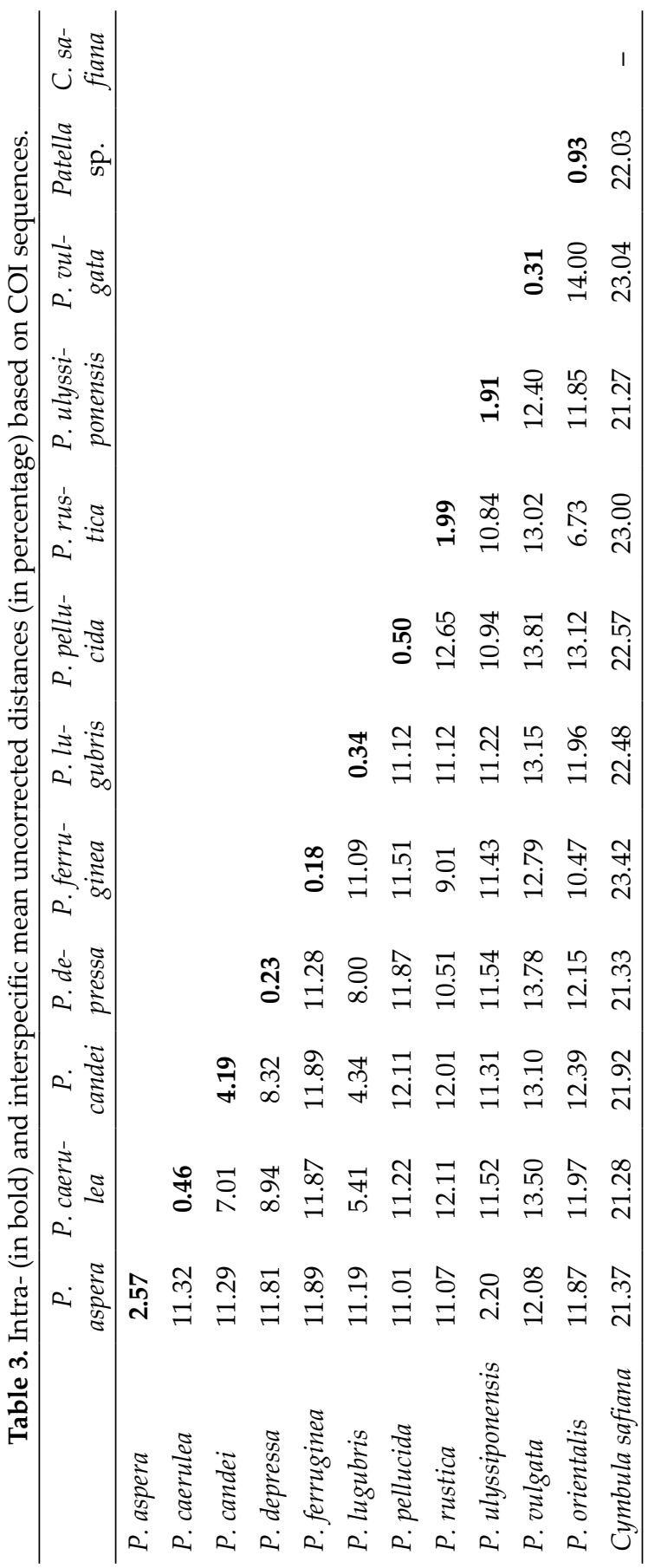

cluster respect to $P$. rustica. Furthermore, the phylogenetic relationship between $P$. ferruginea, $P$. rustica, and P. orientalis could not be resolved with high support.

A final main cluster, consisting of representatives of $P$. pellucida, was observed in a basal position relative to the other Patella species.

Intra- and interspecific distances

To better classify the Algerian samples within species or lineages, intra- and interspecific divergences were calculated. Intraspecific divergences reached values up to $4.19 \%$ for $P$. candei or $2.57 \%$ for P. aspera; in contrast, P. caerulea and $P$. vulgata had values between 0.3 and $0.5 \%$ (Table $3)$.

The lowest interspecific value found was $2.2 \%$ between P. aspera and P. ulyssiponensis. The other interspecific distances ranged from $4.34 \%(P$. candei-P. lugubris) to $14 \%$ ( $P$. vulgata-P. orientalis). However, a clear gap in these values existed when compared to the outgroup, which showed more than $21 \%$ divergence.

When compared to the respective nominal species, the Algerian samples always showed low divergence values. 


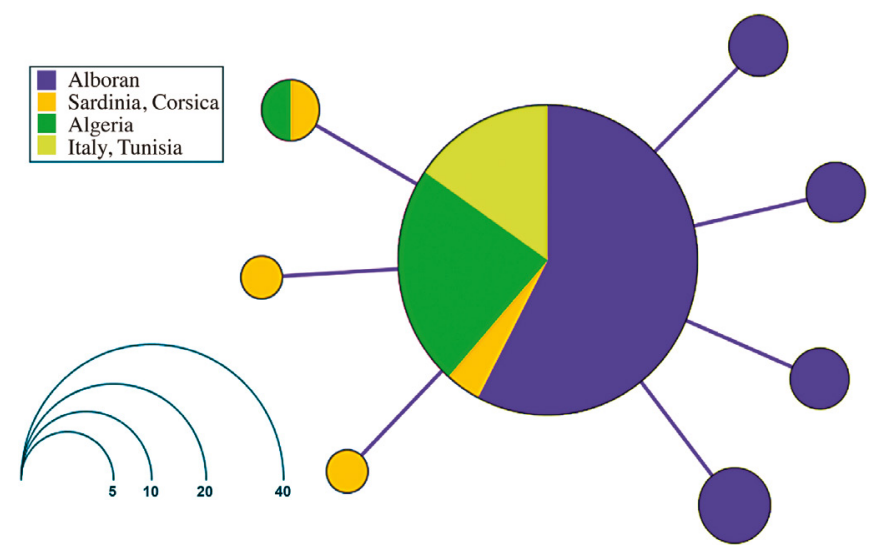

Fig. 3. Patella ferruginea haplotype network

\section{Haplotypes and phylogeographic distribution}

Analysis of the haplotype networks of the three Patella species inhabiting Algerian coasts revealed different topologies. Figure 3 shows a star-like topology for the eight $P$. ferruginea haplotypes and their frequencies. Only a single substitution differentiated the satellite haplotypes from the most frequent one, which was found in samples from all localities included in the analysis. The Algerians samples shared the most frequent haplotype.

For $P$. caerulea, which is also endemic to the Mediterranean, 31 haplotypes were recorded (Fig. 4). In this case, the most frequent haplotype was present in almost all regions, except in the eastern Mediterranean, Tunisia or Sicily. How-

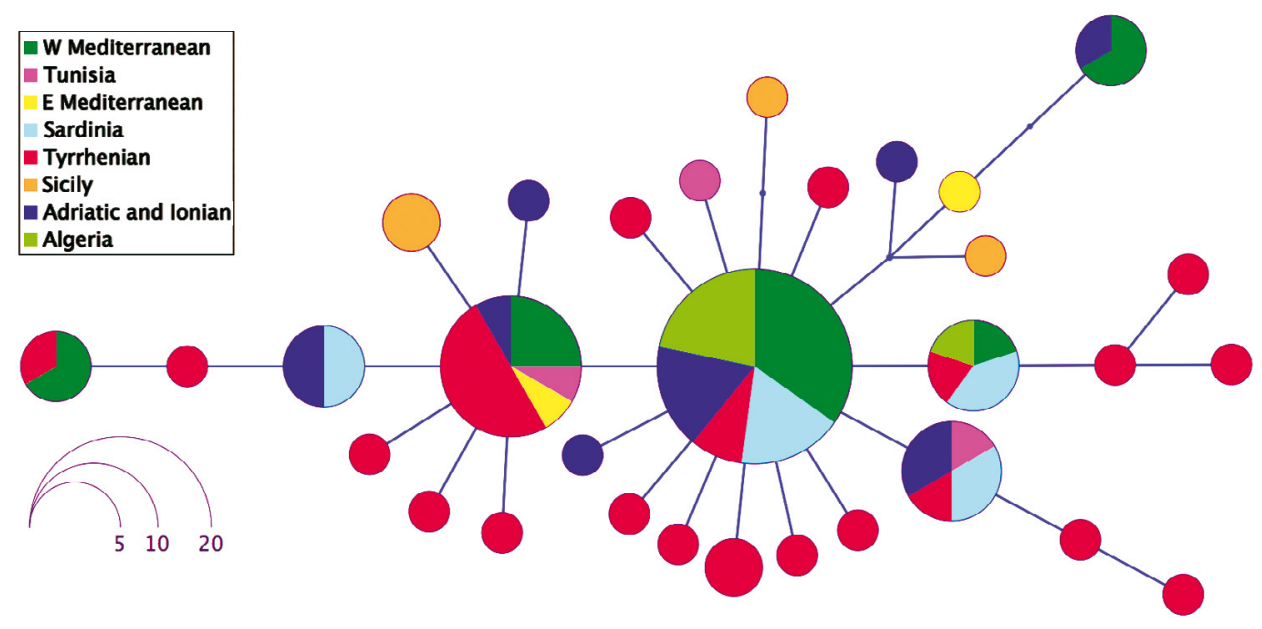

Fig. 4. Patella caerulea haplotype network 
ever, these last localities shared the second most frequent haplotype together with samples from the western Mediterranean, and Tyrrhenian, Adriatic and Ionian Italian coasts. Differentiated by only one substitution from others but not sharing any haplotype appeared those from Sicily. Thus, except the Sicilian samples, in all the others localities shared haplotypes with at least one region were present, lacking an apparent biogeographic structure. Two different haplotypes were found for the Algerian specimens: one coincided with the most frequent haplotype, while the other was shared with specimens belonging to Sardinian, Tyrrhenian and Iberian localities.

For P. rustica, the haplotype network shows 64 haplotypes (Fig. 5). This network not only included the greatest number of haplotypes but also the most differentiated. The eastern and central Mediterranean and Macaronesian representatives had the highest number of substitutions compared to the rest. The Algerian haplotypes appeared in a core group, consisting of specimens primarily from Atlantic and west Mediterranean localities. In addition to the main haplotype shared by Algerian specimens, one Algerian sample has one minority haplotype in common with an Atlantic specimen. Two unique haplotypes were also detected in the Algerian samples.

\section{DISCUSSION}

Overall, our analyses of Patella COI haplotypes, which included both newly reported (this study) and previously obtained haplotypes (MAURO et al. 2003, Sá-Pinto et al. 2005, 2008, 2010, 2012, Espinosa \& Ozawa 2006, NaKano \& Ozawa 2007, Borrell et al. 2010, Casu et al. 2010, Ribeiro et al. 2010, Espinosa et al. 2010, Casu et al. 2011, Muñoz-Colmenero et al. 2012, Villamore et al. 2014) has permitted to situate the samples analysed from the Oran's coasts within the Mediterranean patellid diversity. All these samples were included

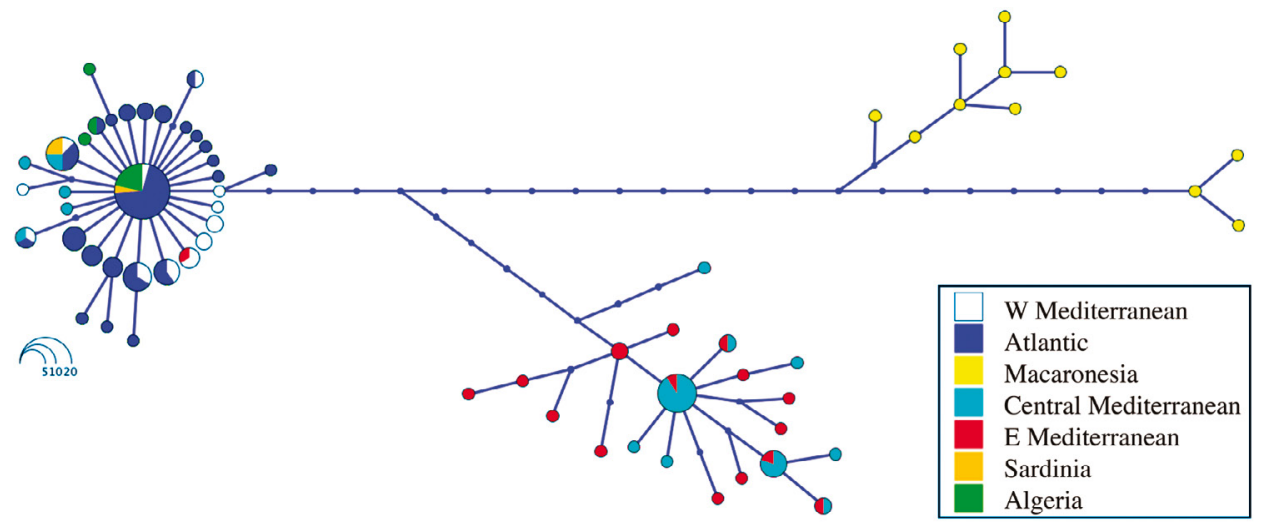

Fig. 5. Patella rustica haplotype network 
in lineages previously defined in different phylogenetic studies (e.g. KoufoPANOu et al. 1999, Sá-Pinto et al. 2005, CAsu et al. 2010). Moreover, with the exception of the high intraspecific divergence among $P$. candei samples and the low interspecific divergence between $P$. aspera and $P$. ulyssiponensis, the three species here analysed match the principles for barcoding identification. In fact, the values found for $P$. aspera and $P$. ulyssiponensis probably reveal misidentifications of some GenBank specimens, and the high diversity inside $P$. candei could hide cryptic differentiation.

Despite these misidentifications, the presence of three Patella species along the Algerian coast was confirmed: $P$. ferruginea, $P$. caerulea, and $P$. rustica are distributed in the studied area. Unfortunately, no $P$. ulyssiponensis specimens were found in these localities. Moreover, in the Port of Oran dam, two of these species co-exist on the dam's artificial substrate at high densities: up to 20 individuals/square meter for $P$. ferruginea and 120 individuals/square meter for $P$. rustica (Kallouche 2014a). Interestingly, the density of $P$. ferruginea in this locality, regardless of the methods used to measure it, is several times higher than that found, for instance, in Sardinian protected areas (0.02 individuals/m, Coppa et al. 2012) or on Alboran Island (0.06 individuals $/ \mathrm{m}$, Paracuellos et al. 2003). In any case, this comparison should be taken as a simple indication as differences in census methodologies can greatly bias the figures (Guallart \& Templado 2016). For instance, some studies only consider adults, while others consider all specimens, or the surface analysed could be randomly selected or chosen based on areas where a species is present in certain numbers (for a revision see Guallart \& TEMPLADo 2016).

In both the tree reconstruction and the haplotype network analysis, the Algerian specimens showed no special differentiation with respect to specimens from neighbouring areas. Samples of $P$. ferruginea grouped with the other representatives of the species in a fully-supported lineage that clustered with $P$. rustica and $P$. orientalis. Nevertheless, the relationships between $P$. ferruginea and the other two taxa were not well determined. In terms of diversity, only one haplotype, corresponding to the most frequent one, was shared among all $P$. ferruginea studied populations. Only seven other haplotypes, differing in a single substitution from the central one, were reported, resulting in a clear star-like shape. This topology usually indicates non-structured populations that suffered a selective sweep or reduction of effective size and that could currently be in expansion. Poor diversity is a general feature for this species in all its remaining populations, as is a lack of population structure, with the exception of slight differentiation within the Corsican-Sardinian populations (Espinosa \& Ozawa, 2006, Casu et al. 2011, Cossu et al. 2017).

In contrast to $P$. ferruginea, within the $P$. rustica cluster, different lineages appeared. Moreover, the topology of the network indicates great differentiation, mostly for specimens distributed in the central and eastern Mediterra- 
nean and the Macaronesian islands. In the latter case, none of the haplotypes were shared with any of the other P. rustica representatives. SÁ-Pinto et al. (2010, 2012) previously suggested the existence of different clusters in the Mediterranean and Atlantic, two of which are in the eastern Mediterranean. The Algerian samples analysed here were included in the western Mediterranean and close Atlantic waters group. Patella rustica appears to be the most diverse of the three species analysed, not only because of the number of haplotypes observed, but also because the Algerian samples presented unique haplotypes, while samples of the other two species always shared haplotypes with other areas.

Algerian populations of $P$. caerulea shared haplotypes with north- and southwestern Mediterranean populations. The most differentiated and diverse populations are those from Tunisia and Italy; however, they do not form a structured group as the different haplotypes are derived from the most common ones. Moreover, the Almeria-Oran Front, considered a potential gene flow barrier for patellids (SÁ-Pinto et al. 2012), does not appear to biogeographically limit $P$. caerulea populations dispersion or connectivity.

Despite belonging to the same area and even the same localities, the three species from the Algerian coast showed different degrees of genetic diversity and population structure. A similar number of specimens were analysed for $P$. caerulea and $P$. rustica and almost double the number for $P$. ferruginea. Even though greater sampling effort was made for the endangered $P$. ferruginea, this species presented the lowest number of haplotypes.

In the past, $P$. ferruginea populations were widely present at high densities throughout the western Mediterranean basin (Lozet \& Dejean-Arrecgros 1977, Beaufort et al. 1987, Laborel-Deguen \& Laborel 1990). Nowadays, this species is experiencing an alarming regression, having disappeared in many areas (Laborel-Deguen et al. 1993, Culioli 2002). Indeed, only a few populations, which are also in decline, remain thus resulting in its status as an endangered species (Templado et al. 2004). Although two significantly different morphotypes have been described, lamarcki and rouxi, according to Porcheddu and Milella (1991), genetic evidences for such differentiation were not observed by Espinosa and Ozawa (2006), nor in this study. Dense populations of $P$. ferruginea have been reported on the Algerian coasts, especially in inaccessible or isolated places such as Plana Island, Habibas Island (Espinosa, 2009), and Rechgoun Island (TAibi et al. 2014) and in prohibited/ restricted areas (Oran Port, the cited Habibas Island, and militarized zones). Therefore, these populations have not been overconsumed or stressed, except for large specimens sacrificed for their shells for trophies, souvenirs, and decoration. However, in recent years, limpets have been increasingly used as fish bait and in some areas where fishing occurs throughout the year, we note the complete absence of limpets. Thus, even if the Algerian coasts harbour ones of 
the few and more abundant $P$. ferruginea populations, our molecular analyses also show a lack of differentiation, thus indicating an impoverished situation, similar to other extant populations.

However, the contrasting results of $P$. ferruginea compared to the other two limpet species in the area ( $P$. caerulea and $P$. rustica) raise questions about the factors influencing the low genetic diversity in P. ferruginea. CAsu et al. (2011) hypothesized that selection could explain the patterns observed in this species. Furthermore, by analysing a large dataset that included different animal groups, BAzIN et al. (2006) concluded that mtDNA variation in invertebrates would not reflect population size, body size or ecology, claiming that positive selection is, in fact, acting on this putative neutral marker (GILLEPSIE 2001). Differences in the timing of the last selective sweep event could be key for explaining mitochondrial diversity (BAzIN et al. 2006), such that the species analysed here, despite having the same life cycle pattern and habitat, are or were subjected to different evolutionary forces. Even if these differences are reflected in the mitochondrial gene analysed (i.e. COI), complementary nuclear data analyses are necessary to better understand the processes that led to their current situations. The existence of Atlantic populations of $P$. rustica could be part of the response of the differential diversity patterns. The variation provided by gene flow with the Atlantic populations, which likely experience different phenomena than those in the Mediterranean (e.g. changes in temperature or water currents), might explain the greater diversity found in Mediterranean populations of $P$. rustica.

Abiotic factors such as temperature, surface currents, and hydrodynamics affect reproduction, occasional long-term dispersion, and oxygenation and organismal respiration in coastal areas, respectively. The three Patella species analysed here all share the same Mediterranean habitat, and therefore, should experience the same abiotic factors. However, biotic factors such as predation e.g. by seabirds (gulls), crabs (Eriphia verrucosa and Pachygrapsus marmoratus), or another gastropod (Stramonita haemastoma) (Guallart \& Templado 2012), can differentially impact the three species. According to Muñoz-Colmenero et al. (2012), rapid climate change or natural catastrophes can also affect patterns of distribution. It is currently unknown if the temperature increase in the Mediterranean (VARGAS-YÁñez et al. 2010) partially explains the results observed in this study. However, the reduction of $P$. ferruginea populations seems to precede such increases as the species was widely distributed until the Palaeolithic (Templado \& Calvo 2004) when it started to decline.

In addition to environmental changes, the influence of anthropogenic activities should be taken into account, having played a very important role in recent decades: fishing, shell harvesting, pollution and coastal development have all caused havoc on different coastal ecosystems (KaLlouche et al. 2014b). Actually, Marra et al. (2016) highlighted how human activity is detrimentally 
impacting $P$. ferruginea since the best Sardinian populations were just those most inaccessible. Thus, the human mediated effect of population bottleneck cannot be neglected to explain the loss of haplotypic diversity.

The slight genetic differentiation between western and eastern Mediterranean basin samples (Fig. 2) and the lack of differentiation among western Mediterranean samples suggest that $P$. caerulea forms a very large unique population. It also suggests that Mediterranean currents provide $P$. caerulea planktonic larvae sufficient dispersion abilities to cause genetic homogeneity across the Mediterranean Sea. Unlike the life histories of other limpets, such as P. vulgata, P. candei, or P. rustica (Côrte-Real et al. 1996, Sá-Pinto et al. 2008), for which structured genetic variation has been observed at similar spatial scales, $P$. caerulea does not show such genetic variability.

During the Last Glacial Maximum (18,000 years ago), the sea level was about $100 \mathrm{~m}$ below the current mean water level. Only in the past 10,000 years has the Mediterranean flooded again, thus leading to recent colonization by certain marine flora and fauna from the Atlantic (Thiede 1978, Hewitt 2000). Conversely, other species' distributions might be the consequence of much older events, such as the existence of refugia during the Messinian salinity crisis (Calvo et al. 2015).

Genetic similarities in Mediterranean $P$. caerulea populations may reflect past founder effects linked with colonization after the Pleistocene glaciations (FAuvelot et al. 2009). Indeed, several studies have recently stressed the relevance of palaeoecological events in determining genetic patterns in marine populations (FAuvelot et al. 2003, Imron et al. 2007, Virgilio et al. 2009, WiLson 2006, Fauvelot et al. 2009).

In addition to possible historical palaeogeographic signals, as Fauvelot et al. (2009) suggested, gene flow is modulated by factors affecting life histories and ocean dynamics. The differences found for the three limpet species in the Oran area indicate that some factors, such as timing of gamete release, could affect dispersion and thus, the genetic structure or diversity observed in a species.

Overall, this study has verified the presence of three Patella species along the Oran's coasts ( $P$. caerulea, $P$. rustica, and the endangered $P$. ferruginea). Although having a shared habitat, molecular and network analyses show distinct patterns of genetic structure and diversity for the different species. In the case of $P$. ferruginea, while Algerian populations do not differ from other Mediterranean and Atlantic populations, they represent ones of the few remnant populations; therefore, strict surveillance and conservation plans must to be implemented to safeguard their survival. The existence of endemic haplotypes in the Algerian P. rustica populations is also noteworthy. Moreover, the geographic situation of the Algerian populations in the Maghrebian coast assures the continuity of populations; for species with restricted larval dispersion, this continuity can be crucial for survival. 
Acknowledgements - Our gratitude to Dr. Templado and Dr. Buckley for greatly improving this manuscript. We thank the Algerian "Commissariat National du Littoral" for the sampling permit granted. Melinda Modrell carefully reviewed the language. This study was funded by the project of the Ministry of Economy and Competitiveness REF. CTM2014-57949-R.

\section{REFERENCES}

Bazin, E., Glémin, S. \& Galtier, N. (2006): Population size does not influence mitochondrial genetic diversity in animals. - Science 312: 570-572. https://doi.org/10.1126/science.1122033

BeAufort, F. \& LACAZE, J. C. (1987): Livre rouge des espèces menacées en France: tome 2, espèces marines et littorales menacées. - Ed. Muséum National d'Histoire Naturelle, Paris, 356 pp.

Beldi, H., Boumaza, F. Z., Draredja, B. \& Soltani, N. (2012): Biodiversité des Patellidae (Gastropoda, Prosobranchia) du golfe d'Annaba (Algérie Nord-Est). - Bulletin de la Société Zoologique de France 137: 121-132.

Borrell, J. Y., Romano, F., Vázquez, E., Blanco, G. \& Sánchez Prado, J. A. (2010): DNA Barcoding and Phylogeny of Patellids from Asturias (Northern Spain). Pp. 281-287. In: Nimis, P. L. \& Vignes Lebbe, R. (eds): Tools for identifying biodiversity: Progress and problems. - Trieste University, Italy.

Boudouresque, C. F., Beaubrun, P. C., Relini, G., Templado, J., Van Klaveren, M. C., Van Klaveren, P., Walmsley, J. G. \& Zotier, R. (1996): Critères de sélection et Liste révisée d'espèces en danger et menacées (marines et saumâtres) en Méditerranée, Programme des Nations Unies pour l'environnement (Rac/Spa Tunis). - GIS Posidonie Publishers, Marseille. 73 pp.

Boumaza, S. \& Semroud, R. (2001): Inventaire de la population de Patella ferruginea Gmelin, 1791 des îles Habibas (Ouest Algerien). - Congrès de la Commission Internationale pour l'Exploration Scientifique de la Mer Méditerranée 36: 361.

Branch, G. M. (1985): Limpets: evolution and adaptation. Pp. 187-220. In: Trueman, E. R. \& Clarcke, M. R. (eds): The Mollusca. Vol. 10. Evolution. - Academic Press, New York. https://doi.org/10.1016/B978-0-12-751410-9.50012-5

Cabral, J. P. (2007): Shape and growth in European Atlantic Patella limpets (Gastropoda, Mollusca). Ecological implications for survival. - Web Ecology 7: 11-21. https://doi. org/10.5194/we-7-11-2007

Calvo, M., Alda, F., Oliverio, M., Templado, J. \& Machordom, A. (2015): Surviving the Messinian salinity crisis? Divergence patterns in the genus Dendropoma (Gastropoda: Vermetidae) in the Mediterranean Sea. - Molecular Phylogenetics and Evolution 91: 17-26. https://doi.org/10.1016/j.ympev.2015.05.004

Casu, M., Casu, D., Lai, T., Cossu, P. \& Curini-Galletti, M. (2006): Intersimple sequence repeat markers reveal strong genetic differentiation among populations of the endangered mollusc Patella ferruginea (Gastropoda: Patellidae) from two Sardinian marine protected areas. - Marine Biology 149: 1163-1174. https://doi.org/10.1007/ s00227-006-0255-y

Casu, M., Sanna, D., Cristo, B., Lai, T., Dedola, G. L. \& Curini-Galletti, M. (2010): COI sequencing as tool for the taxonomic attribution of Patella spp. (Gastropoda): the case of morphologically undistinguishable juveniles settled on a Patella ferruginea 
adult. - Journal of the Marine Biological Association of the United Kingdom 90: 1449-1454. https://doi.org/10.1017/S0025315409991603

Casu, M., Rivera-Ingraham, G. A., Cossu, P., Lai, T., Sanna, D., Dedola, G. L., Sussarellu, R., Sella, G., Benedetto, C., Curini-Galletti, M., Garcia-Gomez, J. C. \& Espinosa, F. (2011): Patterns of spatial genetic structuring in the endangered limpet Patella ferruginea: implications for the conservation of a Mediterranean endemic. - Genetica 139: 1293-1308. https://doi.org/10.1007/s10709-012-9631-3

Coppa, S., De Lucia, G. A., Massaro, G. \& Magni, P. (2012): Density and distribution of Patella ferruginea in a Marine Protected Area (western Sardinia, Italy): Constraint analysis for population conservation. - Mediterranean Marine Science 13: 108-117. http://dx.doi.org/10.12681/mms.27

Côrte-Real, H. B., Macaulay, V. A., Richards, M. B., Hariti, G., Issad, M. S., CambonThomsen, A., Papiha, S., Bertranpetit, J. \& Sykes, B. C. (1996): Genetic diversity in the Iberian Peninsula determined from mitochondrial sequence analysis. - Annals of Human Genetics 60: 331-350. https://doi.org/10.1111/j.1469-1809.1996.tb01196.x

Cossu, P., Dedola, G. L., Scarpa, F., Sanna, D., Lai, T., Maltagliati, F., Curini-Galletti, M. \& CAsu, M. (2015): Patterns of spatial genetic variation in Patella ulyssiponensis: insights from the western Mediterranean marine ecoregion. - Hydrobiologia 755: 39-55. https://doi.org/10.1007/s10750-015-2216-2

Cossu, P., Scarpa, F., Dedola, G. L., Sanna, D., Lai, T., Cristo, B., Curini-Galletti, M., Panzalis, P., Navone, A., Careddu, G., Congiatu, P. P., Mura, L., Fois, N. \& Casu, M. (2017): Surviving at the edge of a fragmented range: patterns of genetic diversity in isolated populations of the endangered giant Mediterranean limpet (Patella ferruginea). - Marine Biology 164: 41. https://doi.org/10.1007/s00227-017-3080-6

Culioli, J. M. (2002): La patelle géante, La pointe de la Corse. - Association Finocchiarola pour la gestion des espaces naturels de la Pointe du Cap Corse 2: 16 pp.

Doneddu, M. \& Manunza, B. (1992): Valutatione dell'impatto antropicorelativo alla balneazione estiva su una popolazione di Patella ferruginea Gmelin, 1791 del littorale de Aglientu. - Bolletino Malacologico 28: 161-168.

Espinosa, F. (2006): Caracterización biológica del molusco protegido Patella ferruginea Gmelin, 1791 (Gastropoda: Patellidae): bases para su gestión y conservación. - PhD thesis, University of Sevilla, Spain.

Espinosa, F. \& Ozawa, T. (2006): Population genetics of the endangered limpet Patella ferruginea (Gastropoda: Patellidae): taxonomic, conservation and evolutionary considerations. - Journal of Zoological Systematics and Evolutionary Research 44: 8-16. https:// doi.org/10.1111/j.1439-0469.2005.00348.x

EspinosA, F. (2009): Populational status of the endangered mollusc Patella ferruginea Gmelin, 1791 (Gastropoda: Patellidae) in Algerian islands (SW Mediterranean). - Animal Biodiversity and Conservation 32: 19-28.

Espinosa, F., Nakano, T., Guerra-García, J. M. \& García-Gómez, J. C. (2010): Population genetic structure of the endangered limpet Cymbula nigra in a temperate Northern hemisphere region: influence of palaeoclimatic events? - Marine Ecology 32: 1-5. https://doi.org/10.1111/j.1439-0485.2010.00410.x

Fauvelot, C., Bernardi, G. \& Planes, S. (2003): Reductions in the mitochondrial DNA diversity of coral reef fish provide evidence of population bottlenecks resulting from Holocene sea-level change. - Evolution 57: 1571-1583. https://doi.org/ 10.1111/j.0014-3820.2003.tb00365.x

Fauvelot, C., Bertozzi, F., Costantini, F., Airoldi, L. \& Abbiati, M. (2009): Lower genetic diversity in the limpet Patella caerulea on urban coastal structures compared 
to natural rocky habitats. - Marine Biology 156: 2313-2323. https://oi.org/10.1007/ s00227-009-1259-1

Folmer, O., Black, M., Hoen, W., Lutz, R. A. \& Vrijenhoek, R. (1994): DNA primers for amplification of mitochondrial cytochrome c oxidase subunit I from diverse metazoan invertebrates. - Molecular Marine Biology and Biotechnology 3: 294-299.

Frenkiel, L. (1975): Contribution à l'étude des cycles de reproduction des Patellidae en Algérie. - Pubblicazioni della Stazione Zoologica di Napoli 39 (suppl.): 153-189.

Frenkiel, L. \& MouËzA, M. (1982): Ecologie des Patellidae dans différents biotopes de la cote Algerienne. - Malacologia 22: 523-530.

Gillespie, J. H. (2001): Is the population size of a species relevant to its evolution? - Evolution 55(11): 2161-2169. https://doi.org/10.1111/j.0014-3820.2001.tb00732.x

Gofas, S. (2015): Patella Linnaeus, 1758. In: MolluscaBase (2016). World Register of Marine Species. http://www.marinespecies.org/aphia.php?p=taxdetails\&id=138312 [July 2016]

Guallart, J. \& Templado, J. (2012): Patella ferruginea. 86 pp. In: Bases ecológicas preliminares para la conservación de las especies de interés comunitario en España: Invertebrados. - Ministerio de Agricultura, Alimentación y Medio Ambiente, Madrid.

Guallart, J., Acevedo, I., Calvo, M. \& Machordom A. (2013a): Protocolo no letal para la obtención de muestras de tejido (para estudios genéticos) en la lapa amenazada Patella ferruginea (Mollusca, Patellidae). - Iberus 31: 171-174.

Guallart, J., Calvo, M., Acevedo, I. \& Templado, J. (2013b): Two-way sex change in the endangered limpet Patella ferruginea (Mollusca, Gastropoda). - Invertebrate Reproduction and Development 57: 247-253. https://doi.org/10.1080/07924259.2012.754794

Guallart, J. \& Templado, J. (2016): Distribution, abundance and habitat selection of Patella ferruginea in Chafarinas Islands (Southwestern Mediterranean Sea). - Iberus 34: $127-162$.

Guindon, S., Dufayard, J.-F., Lefort, V., Anisimova, M., Hordijk, W. \& Gascuel, O. (2010): New algorithms and methods to estimate maximum-likelihood phylogenies: assessing the performance of PhyML 3.0. - Systematic Biology 59: 307-321. https://doi. org/10.1093/sysbio/syq010

Hewitт, G. M. (2000): The genetic legacy of the Quaternary ice ages. - Nature 405: 907-913. https://doi.org/10.1038/35016000

Huelsenbeck, J. P. \& Ronquist, F. (2001): MRBAYES: Bayesian inference of phylogenetic trees. - Bioinformatics 17: 754-755. https://doi.org/10.1093/bioinformatics/17.8.754

Imron, J. B., Hale, P., Degnan, B. M. \& Degnan, S. M. (2007): Pleistocene isolation and recent gene flow in Haliotis asinina, an Indo-Pacific vetigastropod with limited dispersal capacity. - Molecular Ecology 16: 289-304. https://doi.org/10.1111/j.1365294X.2006.03141.x

Kallouche, M. M., Bouras, D., Ghalek, M. \& Abdelghani, F. (2011): Aspect et répartition de la patelle commune méditerranéenne (Patella caerulea) de la zone côtière oranaise (littoral algérien occidental). - Coastal and Maritime Mediterranean Conference Edition 2, Tanger, Maroc, Paralia, Available online: 355-360. https://doi.org/10.5150/ $\mathrm{cmcm} .2011 .074$

Kallouche, M., Bouras, D., Ghalek, M. \& Lekehal, M. (2012): Analyse morpho-histologique de la patelle plane Patella rustica de la côte oranaise (Algérie nord occidentale). - Bulletin de l'Environment du Litoral Oranais 1: 106-112.

Kallouche, M., Bouras, D. \& Hussein, K. B. (2014a): Faunal composition, distribution and richness of the Oran's intertidal coastal zone (Mediterranean Sea, Algeria). - Journal of Biodiversity and Environmental Sciences 5: 122-132. 
Kallouche, M. M., Bouras, D. \& Hussein, K. B. (2014b): The biotic and abiotic factors affecting the biodiversity on intertidal zone of the Mediterranean Sea: Algerian west coast case. - Proceedings of BEL 03, 26-28 November 2013, Oran, Algeria: 225-232 pp.

Koufopanou, V., Reid, D. G., Ridgway, S. A. \& Thomas, R. H. (1999): A molecular phylogeny of the patellid limpets (Gastropoda: Patellidae) and its implications for the origins of their antitropical distribution. - Molecular Phylogenetics and Evolution 11: 138-156. https://doi.org/10.1006/mpev.1998.0557

Laborel-Deguen, F. \& Laborel, J. (1990): Nouvelles données sur la patelle géante Patella ferruginea Gmelin en Méditerranée. I. Statut, répartition et étude des populations. Haliotis 20: 41-54.

Laborel-Deguen, F. \& Laborel, J. (1991): Nouvelles observations sur la population de Patella ferruginea Gmelin de Corse. Pp. 119-128. In: Boudouresque, C. F., Avon, M. \& Gravez, V. (eds): Les espèces marines à protéger en Méditerranée. - GIS Posidonie Publishers, Marseille.

Laborel-Deguen, F., Laborel, J. \& Morhange, C. (1993): Appauvrissement des populations de la patelle géante Patella ferruginea Gmelin, 1791 (Mollusca, Gasteropoda, Prosobranchiata) des côtes de la Réserve marine de Scandola (Corse du Sud) et du Cap Corse (Haute Corse). - Travaux Scientifiques du Parc Naturel Regional et des Reserves Naturelles de Corse 41: 25-32.

Lewis, J. R. \& Bowman, R. S. (1975): Local habitat-induced variations in the population dynamics of Patella vulgata L. - Journal of Experimental Marine Biology and Ecology 17: 165-203. https://doi.org/10.1016/0022-0981(75)90029-5

Lozet, J.-B. \& Dejean-Arrecgros, J. (1977): Je découvre les coquillages: côtes européennes et méditerranéennes. - Lesson Ed., Paris. 132 pp.

Maatallah, R., Cheggour, M., Louadi, K. \& Djebar, A. B. (2014): Les Gastéropodes Patellidae et leur utilisation dans l'évaluation de la pollution du littoral de Skikda (Nord Est de l'Algérie), Gastropods Patellidae and their use in assessment of the pollution on the coastline of Skikda (North East Algeria). - Revue CAMES 2: 15-29.

Machordom, A., Araujo, R., Erpenbeck, D. \& Ramos, M. A. (2003): Phylogeography and conservation genetics of endangered European Margaritiferidae (Bivalvia: Unionoidea). - Biological Journal of the Linnean Society 78: 235-252. https://doi.org/10.1046/ j.1095-8312.2003.00158.x

Machordom, A., Ramirez-Escobar, U., Acevedo, I., Garcia-Jimenez, R., Cabezas, P., Calvo, M., Toledo, C. \& Bloor, P. (2010): Isolation and characterisation of polymorphic microsatellite markers for the endangered ferreous limpet Patella ferruginea (Gastropoda, Patellidae). - Conservation Genetics 11: 1083-1086. https://doi.org/10.1007/ s10592-009-9813-4

Marra, S., De Lucia, G. A., Camedda, A., Espinosa, F. \& Coppa, S. (2016): New records of the distribution and conservation status of the endangered limpet Patella ferruginea in Sardinia (Italy, W Mediterranean). - Aquatic Conservation: Marine and Freshwater Ecosystems 26: 607-612. https://doi.org/10.1002/aqc.2615

Mauro, A., Arculeo, M. \& Parrinello, N. (2003): Morphological and molecular tools in identifying the Mediterranean limpets Patella caerulea, Patella aspera and Patella rustica. - Journal of Experimental Marine Biology and Ecology 295: 131-143. https://doi. org/10.1016/S0022-0981(03)00291-0

Mmonwa, K. L., Teske, P. R., McQuaid, C. D. \& Barker, N. P. (2017): Evolution of foraging behaviour: Deep intra-generic genetic divergence between territorial and nonterritorial southern African patellid limpets. - Molecular Phylogenetics and Evolution, in press. http://dx.doi.org/10.1016/j.ympev.2017.05.024 
Muñoz-Colmenero, M., Turrero, P., Horreo, J. L. \& Garcia-Vazquez, E. (2012): Evolution of limpet assemblages driven by environmental changes and harvesting in North Iberia. - Marine Ecology Progress Series 466: 121-131. https://doi.org/10.3354/meps09906

Nakano, T. \& Ozawa, T. (2007): Worldwide phylogeography of limpets of the order Patellogastropoda: molecular, morphological and palaeontological evidence. - Journal of Molluscan Studies 73: 79-99. https://doi.org/10.1093/mollus/eym001

Pallary, P. (1900): Coquilles marines du littoral du Département d'Oran. - Journal de Conchyliologie 48(3): 211-422.

Paracuellos, M., Nevado, J. C, Moreno, D., Giménez, A. \& Alesina, J. J. (2003): Conservational status and demographic characteristics of Patella ferruginea Gmelin, 1791 (Mollusca, Gastropoda) on the Alboran Island (Western Mediterranean). - Animal Biodiversity and Conservation 26: 29-37.

Payraudeau, B. C. (1826): Catalogue descriptif et méthodique des Annélides et Mollusques de l'Ile de Corse. - Académie des Sciences, Paris. 218 pp.

Porcheddu, A. \& Milella, I. (1991): Aperçu sur l'écologie et sur la distribution de Patella ferruginea (L.) Gmelin, 1971 en mers italiennes. Pp. 119-128. In: Boudouresque, C. F., Avon, M. \& Gravez, V. (eds): Les espèces marines à protéger en Méditerranée. - GIS Posidonie Publishers, Marseille.

Ribeiro, P. A, Branco, M., Hawkins, S. J. \& Santos, A. M. (2010): Recent changes in the distribution of a marine gastropod, Patella rustica, across the Iberian Atlantic coast did not result in diminished genetic diversity or increased connectivity. - Journal of Biogeography 37: 1782-1796. https://doi.org/10.1111/j.1365-2699.2010.02330.x

Ridgway, T. M., Branch, G. M. \& Stewart, B. A. (1999): Patella natalensis Krauss, 1848: redescription of an unrecognized limpet from the east coast of South Africa. - Journal of Molluscan Studies 65: 139-142. https://doi.org/10.1093/mollus/65.1.139

Ridgway, T. M., Branch, G. M., Stewart, B. A. \& Hodgson, A. N. (2000): Taxonomic status of the Patella miniata species complex (Mollusca: Gastropoda) in southern Africa. Hydrobiologia 420: 103-118. https://doi.org/10.1023/A:1003941805696

Rivera-Ingraham, G. A., Espinosa, F. \& García-Gómez, J. C. (2011a): Population dynamics and viability analysis for the critically endangered ferruginean limpet. - Journal of Shellfish Research 30: 889-899. https://doi.org/10.2983/035.030.0330

Rivera-Ingraham, G. A., Espinosa, F. \& García-Gómez, J. C. (2011b): Environmentally mediated sex change in the endangered limpet Patella ferruginea (Gastropoda: Patellidae). - Journal of Molluscan Studies 77: 226-231. https://doi.org/10.1093/mollus/eyr007

Ronquist, F. \& Huelsenbeck, J. P. (2003): MRBAYES 3: Bayesian phylogenetic inference under mixed models. - Bioinformatics 19: 1572-1574. https://doi.org/10.1093/bioinformatics/btg180

Sanna, D., Dedola, G. L., Lai, T., Curini-Galletti, M. \& Casu, M. (2012): PCR-RFLP: A practical method for the identification of specimens of Patella ulyssiponensis s. 1. (Gastropoda: Patellidae). - Italian Journal of Zoology 79: 50-59. https://doi.org/10.1080 /11250003.2011.620988

Sà-Pinto, A., Branco, M., Harris, D. J. \& Alexandrino, P. (2005): Phylogeny and phylogeography of the genus Patella based on mitochondrial DNA sequence data. - Journal of Experimental Marine Biology and Ecology 325: 95-110. https://doi.org/10.1016/j. jembe.2005.04.025

SÀ-Pinto, A., Branco, M., Sayanda, D. \& Alexandrino, P. (2008): Patterns of colonization, evolution and gene flow in species of the genus Patella in the Macaronesian Islands. - Molecular Ecology 17: 519-532. https://doi.org/10.1111/j.1365-294X.2007.03563.x 
Sà-Pinto, A., Baird, S. J. E., Pinho, C., Alexandrino, P. \& Branco, M. S. (2010): A threeway contact zone between forms of Patella rustica (Mollusca: Patellidae) in the central Mediterranean Sea. - Biological Journal of the Linnean Society 100: 154-169. https:// doi.org/10.1111/j.1095-8312.2010.01405.x

Sà-Pinto, A., Branco, S. M., Alexandrino, P. B., Fontaine, M. C. \& Baird, S. J. E. (2012): Barriers to gene flow in the marine environment: insights from two common intertidal limpet species of the Atlantic and Mediterranean. - PLoS ONE 7: e50330. https:// doi.org/ 10.1371/journal.pone.0050330

Sella, G., Robotti, C. A. \& Biglione, V. (1993): Genetic divergence among three sympatric species of Mediterranean Patella (Archaeogastropoda). - Marine Biology 115: 401-405. https://doi.org/10.1007/BF00349838

Semroud, R. \& Boumaza, S. (1998): Données préliminaires sur Patella ferruginea Gmelin 1791, des îles Habibas. Journées de la mer «Océan 98», USTHB (Alger), 12-13 May 1998.

Swofford, D. L. (2002): PAUP*: Phylogeny Analysis Using Parsimony (*and other methods). Version 4.0a147. Sinauer Associates Inc., Sunderland, Massachusetts.

Taibi, A., Oubaziz, B., Ghermaoui, M., Kaddour Hocine, A. \& Bendimerad, M. E. (2014): Étude de la biométrie de la Patelle géante Patella ferruginea à l'île de Rachgoun. Proceedings of BEL 03, 26-28 novembre 2013, Oran, Algérie: 584-592.

Templado, J., Calvo, M., Garvía, A., Luque, A. A., Maldonado, M. \& Moro, L. (2004): Guía de invertebrados y peces marinos protegidos por la legislación nacional e internacional. - Organismo Autónomo de Parques Nacionales, Madrid. 214 pp.

Templado, J. (2011): Familia Patellidae. Pp. 84-88. In: Gofas, S., Moreno, D. \& Salas, C. (eds): Moluscos marinos de Andalucía. Vol. 2. - Servicio de publicaciones e intercambio científico, Universidad de Málaga, Málaga, Spain.

Thiede, J. (1978): A glacial Mediterranean. - Nature 276: 680-683. https:/doi.org/ $10.1038 / 276680 \mathrm{a} 0$

Vargas-Yáñez, M., Moya, F., García-Martínez, M. C., Tel, E., Zunino, P., Plaza, F., Salat, J., Pascual, J., López-Jurado, J. L. \& Serra, M. (2010): Climate change in the Western Mediterranean Sea 1900-2008. - Journal of Marine Systems 82: 171-176. https://doi. org/10.1016/j.jmarsys.2010.04.013

Villamor, A., Costantini, F. \& Abbiati, M. (2014): Genetic structuring across marine biogeographic boundaries in rocky shore invertebrates. - PloS ONE 9: e101135. https:// doi.org/10.1371/journal.pone.0101135

Virgilio, M., Fauvelot, C., Costantini, F., Abbiati, M. \& Backeljau, T. (2009): Phylogeography of the common ragworm Hediste diversicolor (Polychaeta: Nereididae) reveals cryptic diversity and multiple colonization events across its distribution. - Molecular Ecology 18: 1980-1994. https://doi.org/10.1111/j.1365-294X.2009.04170.x

Weeks, A. R., Stoklosa, J. \& Hoffmann, A. A. (2016): Conservation of genetic uniqueness of populations may increase extinction likelihood of endangered species: the case of Australian mammals. - Frontiers in Zoology 13: 31. https://doi.org/10.1186/s12983-0160163-z

Wilson, A. B. (2006): Genetic signature of recent glaciations on populations of a near-shore marine fish species (Syngnathus leptorhynchus). - Molecular Ecology 15: 1857-1871. https://doi.org/10.1111/j.1365-294X.2006.02911.x

Received July 27, 2017, accepted February 27, 2018, published May 31, 2018 